\title{
Understanding the Impact and Control of Bovine Viral Diarrhoea in Cattle Populations
}

\author{
Sasha R. Lanyon • Michael P. Reichel
}

Received: 3 March 2013/Revised: 23 June 2013 / Accepted: 25 June 2013/Published online: 1 August 2013

(c) Springer International Publishing AG 2013

\begin{abstract}
Bovine viral diarrhoea (BVD) affects cattle populations around the world, with significant financial consequences. The losses associated with BVD stem from reproductive loss (in acutely infected cattle), poor productivity of immunotolerant, persistently infected cattle, and indirect losses due to increased occurrence of other diseases because of BVD-related immunosuppression. Control or eradication of BVD is a valuable strategy to reduce losses and ease animal suffering and appears economically justified in the many programs active around the world. This review briefly outlines the epidemiology of BVD and explores the financial implications of infection and the measures that can be taken to reduce them, with an emphasis on the role of diagnostic tests in control programs.
\end{abstract}

Keywords Bovine viral diarrhoea $\cdot$ Pestivirus .

Disease control · Economics $\cdot$ Cattle

\section{Introduction}

Bovine viral diarrhoea (BVD) is a viral disease of cattle caused by BVD virus (BVDV), a Pestivirus of the family Flaviviridae [11]. Acute BVDV infection is generally mild or subclinical, and hence, the disease may be endemically present in a herd without the knowledge of the farmer. However, it is widely acknowledged that this seemingly mild disease still has significant financial impact in infected herds $[16,31,32]$. This paper briefly outlines the epidemiology of

S. R. Lanyon $(\bowtie) \cdot$ M. P. Reichel

School of Animal and Veterinary Sciences, University of Adelaide, Roseworthy Campus, Roseworthy, SA 5371, Australia

e-mail: sasha.lanyon@adelaide.edu.au
BVD in order to explore the costs of infection and the measures that can be taken to prevent them, with an emphasis on the role of diagnostic tests in BVD control.

\section{Pathogenesis and Epidemiology of BVDV}

In order to understand the costs associated with BVD, one must first appreciate that it is primarily a disease of the reproductive system, with an element of immunosuppression. The effects of BVDV infection during early gestation have been reviewed by Grooms [22]. That paper describes the low conception and pregnancy rates expected in cohorts of females within which BVDV infection is active. Failure to conceive, early embryonic loss, abortion and stillbirth can all be sequelae of infection [22]. In addition, infection in mid-gestation may result in the birth of calves that are congenitally deformed [75] or specifically immunotolerant to and persistently infected (PI) with BVDV [8]. These PI individuals may suffer from chronic ill-thrift, poor growth rates, increased susceptibility to other disease and poor survivability $[30,73]$. Progression to mucosal disease, with inevitably fatal consequences, occurs by acute infection of a PI animal with the cytopathic strain of BVDV that is antigenically homologous to the persisting strain [7]. Alternatively, PI animals may be clinically healthy [44] and indistinguishable from their herd mates without diagnostic testing. PI animals act as the reservoir of infection and maintain BVD in cattle populations as a result of their persistent shedding of copious amounts of virus in all bodily excretions and secretions; these individuals have permanently high viral titre and are in a persistent state of viraemia [8].

In addition to reproductive disease and creation of PI calves, acute BVDV infection can lead to an increased 
susceptibility to other diseases, including mastitis and respiratory disease, related to the effects of BVDV infection on leukocytes and the immune system [5]. In one study, dairy heifer calves were found to be 2.4 times more likely to have increased respiratory sounds when BVDV was endemically present in the herd [48], while in another, herds containing a PI animal had significantly higher incidence of mortality and respiratory disease [12].

Reported prevalences of BVDV vary substantially, and can be measured as either the prevalence of BVDV-specific antibodies, or the prevalence of BVDV or viral antigen. Prevalence can be recorded at herd level-proportion of positive herds-or at individual level-proportion of positive individuals. Antibody prevalences have been reported from 47.4 to $100 \%$ at a herd level $[23,67]$ and 14 to $69 \%$ at the individual level $[23,71]$, while antigen or PI prevalences have been reported ranging from 4.4 to $40 \%$ at the herd level $[4,67]$ and 0.3 to $10 \%$ at an individual level $[67,76]$ (Table 1).

\section{Financial Costs Associated with BVDV Infection}

The direct costs of BVDV infection are losses from reproductive disease [22], and from the poor performance of the PI animals [30,73]. A component of this loss is directly related to the increased mortality and morbidity of PI animals [30]. This is particularly significant in feedlots. In one case, only three of 28 PI animals survived to slaughter age [73]. Additional losses are accrued in dairy herds as PI dairy cows tend to be in the lowest 10-20\% producing animals in the herd [28]. The loss from PI animals may not be evenly distributed across years, with a cluster of PI calves being born six to eleven months after the introduction or birth of the first PI animal into a naive herd [29].

Indirect costs such as decreased production, poor growth and increased incidence of other diseases also have large associated costs [31, 74]. Due to the complex nature of BVDV infection and spread, the approaches applied to model the losses caused by BVDV infection give only broad estimates and most are likely to underestimate the indirect costs. For example, Pasman et al. [55] in their model do not account for BVDV-related immunosuppression. Nonetheless, cost estimates for both, endemic (ongoing), and epidemic (outbreak) BVDV infection exist.

In an endemic disease situation, BVDV related losses are estimated to be approximately NZ\$11,334-NZ\$29,666 per herd per year (herd size 251-322) [27, 61], £37-NZ\$87 per cow per year $[24,27]$ or $€ 19$ per $1,000 \mathrm{~L}$ milk production [16]. At an industry level, Houe [31,32] notes that estimates of total loss seem to vary from US $\$ 10$ to US $\$ 40$ million per million calvings. Estimated losses due to epidemic BVDV infection include losses of US $\$ 40,000$ US $\$ 100,000$ per herd in Canada [10] and AU\$144,700 in an Australian dairy herd [42], while replacement of PI heifers alone was estimated to cost between NZ\$6,000 and NZ $\$ 11,000$ per affected herd following outbreaks in New Zealand [14]. These costs are summarised (in US dollars) in Table 2.

In addition to the financial costs, animal welfare is impacted by both acute and chronic disease caused by BVDV, or by other diseases that increase in severity, duration and frequency due to BVD-related immunosuppression

Table 1 Reported prevalence of BVDV-specific antibodies, and antigen positives or persistent infections at herd and individual level

\begin{tabular}{|c|c|c|c|c|c|c|}
\hline \multirow[t]{3}{*}{ Country/region } & \multirow[t]{3}{*}{ Year(s) } & \multicolumn{4}{|c|}{ Prevalence $(\%)$} & \multirow[t]{3}{*}{ References } \\
\hline & & \multicolumn{2}{|l|}{ Herd } & \multicolumn{2}{|l|}{ Individual } & \\
\hline & & Antibody & Antigen/PI & Antibody & Antigen/PI & \\
\hline Belgium & 2009-10 & 47.4 & 4.4 & 32.9 & 0.3 & {$[67]$} \\
\hline Somerset, England & 2006 & 57 & 47 & & $0.2-3.1^{\mathrm{a}}$ & [4] \\
\hline Switzerland & 2008 & & 20.02 & & 0.81 & {$[57]$} \\
\hline Orkney, UK & $2001-08$ & & & & $10^{\mathrm{b}}$ & {$[76]$} \\
\hline South Korea & $2004-05$ & 97.8 & & 58 & & [43] \\
\hline Uruguay & $2000-01$ & 100 & & 69 & & {$[23]$} \\
\hline Mashhad, Iran & 2006 & 93.98 & & & & [18] \\
\hline Yucatan, Mexico & $2001-02$ & 60 & & 14 & & [71] \\
\hline Brittany, Western France, 2004 & 2004 & & $<10$ & & & {$[35]$} \\
\hline Sweden & 1993 & 84 & & & & [53] \\
\hline
\end{tabular}

Note table is not exhaustive

${ }^{\text {a }}$ Within infected herds

${ }^{b}$ Of animals tested for antigen 
Table 2 Estimates of costs due to epidemic and endemic BVDV infection from around the world in United States Dollars (USD) (using conversion rates from February 2013)

\begin{tabular}{|c|c|c|c|c|c|}
\hline Cost in USD & Unit & Beef or dairy & $\begin{array}{l}\text { Infection } \\
\text { situation }\end{array}$ & Region & References \\
\hline 9,468 & Per herd $(n=322)$ per year & Dairy & Endemic & New Zealand & {$[61]$} \\
\hline 24,821 & Per herd $(n=251)$ per year & Dairy & & New Zealand & {$[27]$} \\
\hline 25 & Per $1,000 \mathrm{~L}$ milk production & Dairy & & Western France & {$[16]$} \\
\hline 58 & Per cow per year & Beef & & Scotland & {$[24]$} \\
\hline 73 & Per cow per year & Dairy & & New Zealand & {$[27]$} \\
\hline 10-40 million & Per million calvings & Dairy & & Europe & {$[31,32]$} \\
\hline $40,000-100,000$ & Per herd & Dairy, beef, veal & Epidemic & Ontario, Canada & {$[10]$} \\
\hline 148,809 & Per herd $(n=700)$ & Dairy & & Australia & {$[42]$} \\
\hline $5,012-9,204$ & $\begin{array}{l}\text { Per herd }(n=160-380) \text {, replacement } \\
\text { of PI heifers only }\end{array}$ & Dairy & & New Zealand & [14] \\
\hline
\end{tabular}

$[5,45]$. It is also likely that there are social costs associated with BVD infection. For example, BVD may cause stress for farmers managing ill-thrifty, poor producing or clinically affected animals or may hinder free trade within and between regions. While these costs of BVD infection are difficult to quantify, they are important considerations when considering costs of disease and, consequently, benefits of control or eradication.

\section{BVDV Control Strategies}

In response to the financial impact of both endemic and epidemic BVDV infection, control and eradication schemes are, or have been, in place across much of the cattle-producing world, including all or regions of: Austria, Denmark, Finland, France, Germany, Ireland, Italy, the Netherlands, Norway, Scotland, Slovenia, Sweden, Switzerland, and the United States [1, 2, 15, 20, 21, 34, 35, 47, 49, 56, 64, 66, 72, 78]. Details of these schemes are available in the literature.

Common features between these programs can be identified, such as: identifying herds likely to be infected through an initial herd level testing phase; clearance of the virus from the herds through the identification and removal of PI animals; and prevention of re-infection by the ongoing need for high levels of biosecurity [33, 47, 66].

BVDV control schemes are generally designed on the premise that unequivocal identification and elimination of PI individuals from a population will remove the source of infection. Following the eradication phase, reintroduction of BVDV into herds which have been cleared of infection must be prevented. After clearance, the herd will become increasingly immunologically naive to BVDV, and will therefore be at increasing risk of substantial losses should the infection be reintroduced. Outbreaks following the infection of a naive herd have been reported as having a large financial impact $[42,55]$. Protection from re-infection with BVDV may include a combination of measures, such as strict quarantine and trade restrictions, testing of all introduced cattle, testing of bulls in artificial insemination centres and vaccination $[3,34,47]$ (see Table 3: the Swiss eradication campaign, for a recent example).

Therefore, it is clear that diagnostic tests capable of satisfactorily performing several functions are crucial to BVDV control. These functions include: identifying herds likely to be BVDV infected; identifying PI individuals during the clearance phase; detecting animals that pose a re-introduction risk; monitoring populations and; detecting reintroductions. Fortunately, a variety of diagnostic tests for detection of BVDV, antigen or specific antibodies are available (Table 4). These tests are generally considered highly accurate [65], capable of correctly identifying a high proportion of both, positive samples (sensitive) and negative samples (specific).

\section{Application of Diagnostic Tests in Control or Eradication Campaigns}

Identification of Herds Likely to be Infected

When attempting to identify infected herds for the purpose of induction into a regional control scheme, a test with a high diagnostic sensitivity is essential to identify the infected animals or herds. Ideally, the test would also have high specificity to ensure farmer acceptance and uptake.

When vaccination is not employed, the most common method for classifying a herd as likely or unlikely to be infected is screening for antibody prevalence in the herd [33]. This may be achieved through testing bulk milk, multiple individual milk or multiple serum samples [33]. Usually, these samples are tested by antibody enzyme- 
Table 3 Blow out box outlining the recent Swiss bovine viral diarrhoea eradication campaign

\section{A recent example of $B V D V$ control: the Swiss eradication campaign}

The Swiss BVD eradication campaign commenced in 2008 and targeted the entire dairy cattle population, with testing of all individuals in the first year [56]. Follow-up testing of newborn calves followed throughout the second year [it would be impossible to eradicate BVDV in a shorter time frame in the absence of a test capable of detecting PI fetuses in utero (see Identifying PI individuals during the clearance phase)]. The campaign was accompanied by movement controls, preventing cattle from moving between farms (potentially re-infecting clear(ed) properties), only permitting stock moving to slaughter at abattoirs. In a period of 2 years, the Swiss eradication campaign was successful at reducing the proportion of newborn calves that were PI from $1.5 \%$ to $<0.2 \%$, with a total of 12,092 PI animals removed from the population during the first year and 5,199 PI calves detected and culled in the follow-up year [57]. At September 2010, only 404 herds $(<1 \%)$ were still undergoing testing to identify PI animals [57].

Upon completion of eradication, sources of reintroduction must be considered-in Switzerland this includes the beef cattle population (particularly bulls being used in dairy herds [14]), wildlife and other domesticated species (potentially including sheep [36], goats [37] and deer [38]), animals being introduced from other countries and contact with cattle populations in neighbouring countries - especially during summer alpine pasturing [70].

Häsler et al. [26] investigated the economic benefit of the Swiss eradication campaign and concluded that there was a net financial benefit, with long term endemic disease costs that would have continued to be incurred outweighing eradication costs. The break-even point was expected to be reached as early as 2012. In addition to the financial benefits, it is likely that there are both social benefits and animal welfare benefits resulting from eradication. Freedom from this disease is likely to reduce farmer stress associated with management of ill-thrifty, poor producing and clinically affected cattle, while from an animal welfare standpoint, reduction in both acute and chronic disease associated with BVD and BVD-related immunosuppression is a positive outcome.

linked immunosorbent assay (ELISA). Bulk milk testing by antibody ELISA can be used to estimate seroprevalence in the herd $[13,58]$. In France, three consecutive bulk milk antibody tests at 4 month intervals were used to classify as either infected (for follow-up testing for the presence of PI animals) or uninfected herds (clear of the virus) [35], while a single bulk milk antibody ELISA result was used to decide the need (or not) for further herd testing in Norway [77], Finland [62] and Lower Austria [63]. In non-milking (e.g., beef) herds, a serological "spot test"-testing of a representative sample of animals-has been used as an alternative to bulk milk testing [47], with a high number of positive individuals, or a strong reaction to a pooled blood sample indicating a positive herd. This serological approach has been used in Italy [15]. In the Shetland Islands, full herd serology was carried out, with a single antibody positive animal resulting in a positive herd-level classification [72].

In some programs, where a herd returned a high herdlevel antibody result, antibody testing of samples from young stock (e.g., blood from weaned calves or milk from primiparous cows) was used to determine whether the infection was historic or recent, with antibodies in young cattle indicating recent infection [15, 47, 63, 77].

In the Netherlands and Switzerland, herd classification was performed on the basis of total herd viral antigen or virus screening using antigen ELISA or reverse transcriptase-polymerase chain reaction (RT-PCR) on ear-notch samples or (pooled or individual) serum, blood or milk samples $[49,56]$.

The effectiveness of the chosen method is greatly affected by the criteria under which a herd is defined as positive and the cut off thresholds applied to the test. However, antibody screening methods are seen to be highly sensitive for detection of infected herds [15], as the antibody seroprevalence within an infected herd is likely to be very high [33] and easily detectable.

\section{Identifying PI Individuals During the Eradication Phase}

The identification of PI individuals is usually conducted at herd-level, and requires antigen or virus detection methods. However, as PI cattle do not develop BVDV-specific antibodies, antibody screening can be used to identify seropositive cattle, rule them non-PI (as PI individuals will be seronegative), and reduce the number of samples that need to be submitted for the (traditionally more expensive) antigen or virus testing [33].

The antigen ELISA is most commonly used for detecting PI cattle during control schemes [49, 56, 72]. Antigen ELISA has the advantage of being less expensive than RTPCR when used on the large numbers of individual samples as would be experienced in control programs. If pooling of samples can effectively be employed in PCR testing, the testing cost per individual animal can be reduced. Antigen ELISA and PCR are preferable to both: immunohistochemistry as they are not restricted to tissue samples; and immunoperoxidase assay as they do not require cell culture laboratory facilities [65]. In addition, antigen ELISA is preferable to both immunohistochemistry and immunoperoxidase assay as it is less labour intensive. Neither immunohistochemistry nor immunoperoxidase assays are commonly used in control programs.

In Lower Austria, both antigen/serum and antigen/leukocyte ELISAs were utilised (with serial interpretation) to increase certainty in test results [63]. Special testing protocols sometimes exist for young calves, where the presence of maternal antibodies has the potential to interfere 
Table 4 Advantages and disadvantages of the most common diagnostic tests used in BVDV control or eradication programs

\begin{tabular}{|c|c|c|c|c|c|}
\hline Test & $\begin{array}{l}\text { For } \\
\text { detection } \\
\text { of }\end{array}$ & Sample(s) & Advantages & Disadvantages & Countries of use $\mathrm{a}^{\mathrm{a}}$ \\
\hline \multirow[t]{2}{*}{$\begin{array}{l}\text { ELISA } \\
{[13,39,41]}\end{array}$} & \multirow[t]{2}{*}{ Antibodies } & $\begin{array}{l}\text { Serum, } \\
\text { individual } \\
\text { milk }\end{array}$ & $\begin{array}{l}\text { - Inexpensive } \\
\text { - Rapid } \\
\text { - Sensitive }\end{array}$ & $\begin{array}{l}\text { - Normally unable to differentiate } \\
\text { natural and vaccinal antibodies }\end{array}$ & \multirow{4}{*}{$\begin{array}{l}\text { - } \text { Rome } \\
\text { province, Italy } \\
\text { [15] } \\
\text { - Slovenia [21] } \\
\text { - Shetland, } \\
\text { Scotland [72] } \\
\text { - Brittany, } \\
\text { Western France } \\
\text { [35] } \\
\text { - The } \\
\text { Netherlands } \\
\text { [49] } \\
\text { - Finland [62] }\end{array}$} \\
\hline & & Bulk milk & $\begin{array}{l}\text { - Inexpensive } \\
\text { - Rapid } \\
\text { - Sensitive } \\
\text { - Cost effective } \\
\end{array}$ & $\begin{array}{l}\text { - Normally unable to differentiate } \\
\text { natural and vaccinal antibodies } \\
\text { - Does not give information on } \\
\text { individual animals }\end{array}$ & \\
\hline \multirow[t]{2}{*}{$\begin{array}{l}\text { Anti-NS3 } \\
\text { or p80 } \\
\text { ELISA } \\
{[40,60]}\end{array}$} & \multirow[t]{2}{*}{ Antibodies } & $\begin{array}{l}\text { Serum, } \\
\text { individual } \\
\text { milk }\end{array}$ & $\begin{array}{l}\text { - Inexpensive } \\
\text { - Rapid } \\
\text { - Sensitive } \\
\text { - Detects antibodies to natural } \\
\text { infection (but not vaccination) }\end{array}$ & & \\
\hline & & Bulk milk & $\begin{array}{l}\text { - Inexpensive } \\
\text { - Rapid } \\
\text { - Sensitive } \\
\text { - Cost effective } \\
\text { - Detects antibodies to natural } \\
\text { infection (but not vaccination) }\end{array}$ & $\begin{array}{l}\text { - Does not give information } \\
\text { on individual animals }\end{array}$ & \\
\hline \multirow[t]{2}{*}{ ELISA [69] } & \multirow[t]{2}{*}{$\begin{array}{l}\text { Viral } \\
\text { antigen }\end{array}$} & $\begin{array}{l}\text { Serum, } \\
\text { individual } \\
\text { milk }\end{array}$ & $\begin{array}{l}\text { - Inexpensive } \\
\text { - Rapid } \\
\text { - Sensitive for detection of PI } \\
\text { animals } \\
\end{array}$ & $\begin{array}{l}\text { - Can be subject to interference by } \\
\text { colostral antibodies in young } \\
\text { calves }\end{array}$ & \multirow{2}{*}{$\begin{array}{l}\text { - Rome } \\
\text { province, Italy } \\
\text { [15] } \\
\text { - Slovenia [21] } \\
\text { - Shetland, } \\
\text { Scotland [72] } \\
\text { - The } \\
\text { Netherlands } \\
\text { [49] } \\
\text { - Switzerland } \\
\text { [56] }\end{array}$} \\
\hline & & Ear notches & $\begin{array}{l}\text { - Inexpensive } \\
\text { - Rapid } \\
\text { - Sensitive for detection of PI } \\
\text { animals } \\
\text { - May not be subject to interference } \\
\text { by colostral antibodies in young } \\
\text { calves }\end{array}$ & & \\
\hline \multirow[t]{2}{*}{$\begin{array}{l}\text { RT-PCR } \\
{[21,49]}\end{array}$} & \multirow[t]{2}{*}{ Viral RNA } & $\begin{array}{l}\text { Serum, } \\
\text { individual } \\
\text { milk, } \\
\text { ear notches, } \\
\text { saliva, } \\
\text { follicular } \\
\text { fluid }\end{array}$ & $\begin{array}{l}\text { - Rapid } \\
\text { - Highly sensitive, will detect acute } \\
\text { infections } \\
\text { - Not subject to interference by } \\
\text { colostral antibodies in young } \\
\text { calves } \\
\text { - May be used on pooled samples }\end{array}$ & $\begin{array}{l}\text { - Requires more sophisticated } \\
\text { laboratory facilities } \\
\text { - More expensive than ELISA }\end{array}$ & \multirow{2}{*}{$\begin{array}{l}\text { - Slovenia [21] } \\
\text { - Brittany, } \\
\text { Western France } \\
\text { [35] } \\
\text { - The } \\
\text { Netherlands } \\
\text { [49] } \\
\text { - Switzerland } \\
\text { [56] }\end{array}$} \\
\hline & & Bulk milk & $\begin{array}{l}\text { - Rapid } \\
\text { - Highly sensitive, can detect one PI } \\
\text { individual in herd of several } \\
\text { hundred } \\
\text { - Can confirm several hundred } \\
\text { animals as non-PI with single } \\
\text { sample } \\
\text { - Cost-effective }\end{array}$ & $\begin{array}{l}\text { - Requires more sophisticated } \\
\text { laboratory facilities } \\
\text { - Will not detect non-milking PI } \\
\text { animal } \\
\text { - Does not give information on } \\
\text { individual animals }\end{array}$ & \\
\hline
\end{tabular}

${ }^{a}$ Not exhaustive

with antigen ELISA results [6, 68, 80]. Predominantly, these calf testing protocols involve delaying testing until calves are $>10-12$ weeks of age $[49,72]$.
RT-PCR testing of pooled blood is in routine use for PI detection in Somerset, England [4]. Further efforts to reduce the cost of testing for PI cattle may include stratification of 
the herd based on production parameters, as all PI animals identified by Hill et al. [28] were in the lowest 10-20\% producing animals. This approach allows a reduction in the individual number of tests necessary [28]. However, testing all animals in a herd using pooled samples would still be advisable to ensure no higher producing PIs are missed.

Programs which rely on whole-herd PI screening for herdlevel classification, such as those of the Netherlands and Switzerland, have the advantage of completing herd-level classification and PI animal identification in one step. However, the serological status of these herds remains unknown. In such a situation, it is difficult to track the herd for the decline (or absence of decline) in seroprevalence that signifies successful (or not) virus clearance. Similarly, this prevents biosecurity and monitoring procedures from being tailored-for example, it is difficult to assess the value of vaccination or to recognise any change in the serological status that may signal the reintroduction of BVDV.

Follow-up testing of all calves born in the following 9-12 months must be undertaken, to identify any PI animals that were in utero at the time of initial testing.

\section{Detecting Animals Which Pose a Reintroduction Risk}

All new animals being introduced to a BVDV-free herd or region pose a risk for potential reintroduction of the virus. The most effective way of preventing reintroduction to cleared herds is to test all incoming cattle for their BVDV status and to eliminate PI animals. This can be incorporated at the regional level through transport restrictions on animals that have not been BVDV tested. This process is, diagnostically, relatively simple, with antigen ELISA or RT-PCR available for this purpose. Ear notch sampling is particularly valuable in this situation at the herd level, as the sample can be taken by the farmer pre-introduction. Furthermore, commercially available SNAP antigen tests (SNAP BVDV Antigen Test, IDEXX Laboratories Inc., Westbrook, Maine, United States) allow for cow-side testing, with a result returned in $<20$ min. $^{1}$

However, current diagnostic tests are unable to reliably detect PIs in utero, and a cow carrying a PI fetus remains a reintroduction risk. While antibody ELISAs have been applied for this purpose, only low to moderate specificity was achieved at thresholds selected for sensitivity $[9,46]$. These so-called Trojan cows and their in utero PI calves are responsible for a large proportion of re-infections of BVDV into cleared (PI-free) herds. In Denmark, $28 \%$ of reinfections were the result of introduction of a cow carrying a PI fetus [3]. It is commonly recommended that the purchase of

\footnotetext{
${ }^{1}$ IDEXX Laboratories Inc. (2012) IDEXX SNAP BVD Test Validation Data Report. IDEXX Laboratories Inc., Westbrook, Maine, USA.
}

pregnant, seropositive cattle be refused [15, 72] or that the resultant calf be isolated at birth until testing can confirm whether it is PI or not [3]. [Note: while pregnant, seronegative cows do not pose an infection risk in the form of a PI fetus (as the fetus cannot be PI without recent acute infection of the cow), the cow should, as with all seronegative cattle, be tested for PI.] As a cow spends nine of every 12 months pregnant for the majority of her life, restricting trading of pregnant cattle becomes impracticable. A diagnostic test capable of identifying cows carrying PI fetuses would be a useful tool in tackling BVDV [9].

\section{Monitoring for Re-infection}

For the most part, monitoring for reinfection is carried out at herd-level in the form of continued antibody testing of each new cohort of young stock or of the entire herd, with this information incorporated, where relevant, into regional control efforts. In the Netherlands and Norway, pooled milk from primiparous cows or a serum "spot test" from young stock (often replacement heifers) was used for this testing [49, 77]. Regular bulk milk antibody testing has been mentioned as a possible method of tracking the decline in seroprevalence that a virus-free herd would experience over time, with a (potentially slight) rise in bulk milk antibody levels indicating reinfection [33]. The diagnostic value of such a rise will improve as seroprevalence in the herd decreases over time. Here, the benefits of the convenience and low cost of bulk milk antibody testing may allow for more regular testing of herds, while young stock testing is more intensive and may be carried out less frequently. However, it should be noted that a rise in bulk milk antibody levels may result from the introduction of a seropositive cow to a herd in which seroprevalence is low. This may be of particular relevance when a control scheme is not compulsory and herds with high seroprevalence are available as a source for introduced animals. The interpretation of antibodies in young stock may be more straightforward, and allow for more certainty in test results, than a slight rise in bulk milk antibody levels.

\section{A Note on Sources of Reintroduction}

As the population becomes progressively more susceptible to BVDV infection and the occurrence of BVDV PI animals remains low, the true effects of less efficient means of infection transfer will become clear. In the presence of the high infectious pressure from PI individuals, it is easy to discount transmission from acutely infected animals, interspecies transmission and transmission via contaminated equipment such as nose tongs and needles. However, experimentally it has been shown that these routes of transmission are possible $[25,52,54]$. Indeed, reports of 
ongoing virus circulation in herds that were believed to be free of PI animals [50, 51] suggest that these methods of transmission, while less efficient, may be sufficient to maintain the infection until a PI calf is born.

\section{The Use of Diagnostic Tests in Vaccinated Populations}

It has been noted that the eradication of BVDV PI cattle is not achieved at population level when vaccination alone is practised [45, 59], although clearance does occur in some vaccinated herds. Continually waning immunity-either maternal or vaccinated-ensures that less than $100 \%$ of the herd is likely to be immune at any one time. As a result, a vaccinated herd is still likely to contain susceptible animals. This means that BVDV is still a threat in vaccinated herds [45]. This threat may be increased due to an increase in risky behavior, owing to a false sense of security associated with vaccination [45]. As such, diagnostic tests are still required to identify infected, vaccinated herds. However, BVDV vaccine use can complicate the diagnostic testing process and the interpretation of test results. In particular, BVDV antibody testing can be affected, as the assay employed may be unable to distinguish between vaccinal antibody responses to BVDV or antibody responses to field infection [19], thus rendering BVDV antibody-testing ineffective. On the other hand, the use of anti-NS3 or p80 protein ELISAs may allow differential antibody testing [79], focussing on the detection of antibodies directed against nonstructural viral proteins (produced by actively reproducing virus), as compared to the detection of antibodies directed against structural viral proteins (also present in vaccinescontaining inactivated virus). However, a recent study struggled to differentiate between vaccinal antibodies and antibody responses seen during the early post-infection phase [60]. The development of a vaccine allowing the clear differentiation of infected from vaccinated animals would allow a clear distinction between natural immunity and vaccinal antibody. Whole herd PI screening for virus antigen with either antigencapture assays or RT-PCR may be the answer in such situations. While high levels of colostrum-derived antibodies can temporarily reduce the ability of these methods to detect young PI calves [17], the presence of (lower levels of) vaccinal antibodies is unlikely to do so. In dairy herds, this can readily be achieved by utilising a combination of RT-PCR on bulk milk and serological or ear notch testing on non-milking animals. Care should be taken when selecting diagnostic tests for use in vaccinated populations, with careful validation of those tests necessary to ensure confidence in the results.

\section{Conclusion}

Through an understanding of the epidemiology of BVDV infection, the impact of the disease-decreased production, reduced reproductive rate and increased occurrence of other diseases-may be minimised or eliminated through control or eradication. Primarily, BVD control programs aim to eradicate the virus by eliminating the main source of viral spread-PI individuals. An understanding of the available diagnostic tests and their respective strengths and weaknesses allows this to be carried out, both time- and cost-efficiently. Once eradication is complete, it is necessary to put measures in place that maintain freedom from BVDV. This may involve a combination of protective measures to increase biosecurity, including diagnostic testing of introduced stock and vaccination. Both, the Swiss dairy BVDV campaign and the Norwegian BVDV control program have been observed to be economically beneficial $[26,77]$ and are likely to have positive social results and animal welfare outcomes.

Acknowledgments The authors thank Prof. Joe Brownlie (Royal Veterinary College, United Kingdom) and Dr. Fraser Hill (Gribbles Veterinary Pathology, New Zealand) for their feedback and support during the preparation of this review.

\section{References}

1. Anon (2010) Scotland launches a BVD eradication programme. Vet Rec 167:505-505

2. Barrett DJ, More SJ, Graham DA, O'Flaherty J, Doherty ML, Gunn HM (2011) Considerations on BVD eradication for the Irish livestock industry. Ir Vet J 64:1-10

3. Bitsch V, Hansen KEL, Ronsholt L (2000) Experiences from the Danish programme for eradication of bovine virus diarrhoea (BVD) 1994-1998 with special reference to legislation and causes of infection. Vet Microbiol 77:137-143

4. Booth RE, Brownlie J (2012) Establishing a pilot bovine viral diarrhoea virus eradication scheme in Somerset. Vet Rec 170:29-35

5. Brackenbury LS, Carr BV, Charleston B (2003) Aspects of the innate and adaptive immune responses to acute infections with BVDV. Vet Microbiol 96:337-344

6. Brinkhof J, Zimmer G, Westenbrink F (1996) Comparative study on four enzyme-linked immunosorbent assays and a cocultivation assay for the detection of antigens associated with the bovine viral diarrhoea virus in persistently infected cattle. Vet Microbiol $50: 1-6$

7. Brownlie J, Clarke MC, Howard CJ (1984) Experimental production of fatal mucosal disease in cattle. Vet Rec 114:535-536

8. Brownlie J, Clarke MC, Howard CJ, Pocock DH (1987) Pathogenesis and epidemiology of bovine virus diarrhoea infection of cattle. Ann Rech Vet 18:157-166

9. Brownlie J, Hooper LB, Thompson I, Collins ME (1998) Maternal recognition of foetal infection with bovine virus diarrhoea virus (BVDV) - the bovine pestivirus. Clin Diagn Virol $10: 141-150$

10. Carman S, van Dreumel T, Ridpath J, Hazlett M, Alves D, Dubovi E, Tremblay R, Bolin S, Godkin A, Anderson N (1998) Severe acute bovine viral diarrhea in Ontario, 1993-1995. J Vet Diagn Invest 10:27-35

11. Collett MS, Anderson DK, Retzel E (1988) Comparisons of the pestivirus bovine viral diarrhea virus with members of the Flaviviridae. J Gen Virol 69:2637-2643 
12. Dieguez FJ, Yus E, Vilar MJ, Sanjuan ML, Arnaiz I (2009) Effect of the bovine viral diarrhoea virus (BVDV) infection on dairy calf rearing. Res Vet Sci 87:39-40

13. Eiras C, Arnaiz I, Sanjuan ML, Yus E, Dieguez FJ (2012) Bovine viral diarrhea virus: correlation between herd seroprevalence and bulk tank milk antibody levels using 4 commercial immunoassays. J Vet Diagn Invest 24:549-553

14. Ellison R, Hermans R, Clemance M, Voogt J (2005) BVD disasters-they do occur. VetScript 18:30-31

15. Ferrari G, Scicluna MT, Bonvicini D, Gobbi C, Della Verita F, Valentini A, Autorino GL (1999) Bovine virus diarrhoea (BVD) control programme in an area in the Rome province (Italy). Vet Microbiol 64:237-245

16. Fourichon C, Beaudeau F, Bareille N, Seegers H (2005) Quantification of economic losses consecutive to infection of a dairy herd with bovine viral diarrhoea virus. Prev Vet Med 72:177-181

17. Fux R, Wolf G (2013) Transient elimination of circulating bovine viral diarrhoea virus by colostral antibodies in persistently infected calves: a pitfall for BVDV-eradication programs? Vet Microbiol 161:13-19

18. Garoussi MT, Haghparast A, Hajenejad MR (2009) Prevalence of Bovine Viral Diarrhoea virus antibodies among the industrial dairy cattle herds in suburb of Mashhad-Iran. Trop Anim Health Prod 41:663-667

19. Graham DA, German A, Mawhinney K, Goodall EA (2003) Antibody responses of naive cattle to two inactivated bovine viral diarrhoea virus vaccines, measured by indirect and blocking ELISA and virus neutralisation. Vet Rec 152:795-800

20. Greiser-Wilke I, Grummer B, Moennig V (2003) Bovine viral diarrhoea eradication and control programmes in Europe. Biologicals 31:113-118

21. Grom J, Barlic-Maganja D (1999) Bovine viral diarrhoea (BVD) infections - control and eradication programme in breeding herds in Slovenia. Vet Microbiol 64:259-264

22. Grooms DL (2004) Reproductive consequences of infection with bovine viral diarrhoea virus. Vet Clin N Am Food Anim Pract 20:5-19

23. Guarino H, Nunez A, Repiso MV, Gil A, Dargatz DA (2008) Prevalence of serum antibodies to bovine herpesvirus-1 and bovine viral diarrhea virus in beef cattle in Uruguay. Prev Vet Med 85:34-40

24. Gunn GJ, Stott AW, Humphry RW (2004) Modelling and costing BVD outbreaks in beef herds. Vet J 167:143-149

25. Gunn HM (1993) Role of fomites and flies in the transmission of bovine viral diarrhea virus. Vet Rec 132:584-585

26. Häsler B, Howe KS, Presi P, Stärk KDC (2012) An economic model to evaluate the mitigation programme for bovine viral diarrhoea in Switzerland. Prev Vet Med 106:162-173

27. Heuer C, Healy A, Zerbini C (2007) Economic effects of exposure to bovine viral diarrhea virus on dairy herds in New Zealand. J Dairy Sci 90:5428-5438

28. Hill FI, Reichel MP, Tisdall DJ (2010) Use of molecular and milk production information for the cost-effective diagnosis of bovine viral diarrhoea infection in New Zealand dairy cattle. Vet Microbiol 142:87-89

29. Houe H (1992) Age distribution of animals persistently infected with Bovine Virus Diarrhea Virus in 22 Danish dairy herds. Can J Vet Res 56:194-198

30. Houe H (1993) Survivorship of animals persistently infected with bovine virus diarrhea virus (BVDV). Prev Vet Med 15:275-283

31. Houe H (1999) Epidemiological features and economical importance of bovine virus diarrhoea virus (BVDV) infections. Vet Microbiol 64:89-107

32. Houe H (2003) Economic impact of BVDV infection in dairies. Biologicals 31:137-143
33. Houe H, Lindberg A, Moennig V (2006) Test strategies in bovine viral diarrhea virus control and eradication campaigns in Europe. J Vet Diagn Invest 18:427-436

34. Hult L, Lindberg A (2005) Experiences from BVDV control in Sweden. Prev Vet Med 72:143-148

35. Joly A, Fourichon C, Beaudeau F (2005) Description and first results of a BVDV control scheme in Brittany (western France). Prev Vet Med 72:209-213

36. Julia S, Craig MI, Jimenez LS, Pinto GB, Weber EL (2009) First report of BVDV circulation in sheep in Argentina. Prev Vet Med 90:274-277

37. Krametter-Froetscher R, Duenser M, Preyler B, Theiner A, Benetka V, Moestl K, Baumgartner W (2010) Pestivirus infection in sheep and goats in West Austria. Vet J 186:342-346

38. Krametter R, Nielsen SS, Loitsch A, Froetscher W, Benetka V, Moestl K, Baumgartner W (2004) Pestivirus exposure in freeliving and captive deer in Austria. J Wildl Dis 40:791-795

39. Kramps JA, van Maanen C, van de Wetering G, Steinstra G, Quak S, Brinkhof J, Ronsholt L, Nylin B (1999) A simple, rapid and reliable enzyme-linked immunosorbent assay for the detection of bovine virus diarrhoea virus (BVDV) specific antibodies in cattle serum, plasma and bulk milk. Vet Microbiol 64:135-144

40. Kuijk H, Franken P, Mars MH, Bij De Weg W, Makoschey B (2008) Monitoring of BVDV in a vaccinated herd by testing milk for antibodies to NS3 protein. Vet Rec 163:482-484

41. Lanyon S, Anderson M, Bergman E, Reichel MP (2013) Validation and evaluation of a commercially available ELISA for the detection of antibodies specific to bovine viral diarrhoea virus (BVDv) ("bovine pestivirus"). Aust Vet J 91:52-56

42. Lanyon S, Rogers J, Kessell A, Reichel MP (2012) Economic analysis of an acute outbreak of bovine viral diarrhoea virus (BVDv) in a South Australian dairy herd-a case study. Aust Cattle Vet 63:13-17

43. Lee DH, Park SW, Choi EW, Lee CW (2008) Investigation of the prevalence of bovine viral diarrhoea virus in dairy cows in South Korea. Vet Rec 162:211-213

44. Liess B, Orban S, Frey HR, Trautwein G, Wiefel W, Blindow H (1984) Studies on trans-placental transmissibility of a bovine virus diarrhea (BVD) vaccine virus in cattle. 2. Inoculation of pregnant cows without detectable neutralizing antibodies to BVD virus 90-229 days before parturition (51st to 190th day of gestation). J Vet Med Ser B 31:669-681

45. Lindberg A, Brownlie J, Gunn GJ, Houe H, Moennig V, Saatkamp HW, Sandvik T, Valle PS (2006) The control of bovine viral diarrhoea virus in Europe: today and in the future. Rev Sci Tech 25:961-979

46. Lindberg A, Groenendaal H, Alenius S, Emanuelson U (2001) Validation of a test for dams carrying foetuses persistently infected with bovine viral-diarrhoea virus based on determination of antibody levels in late pregnancy. Prev Vet Med 51:199-214

47. Lindberg ALE, Alenius S (1999) Principles for eradication of bovine viral diarrhoea virus (BVDV) infections in cattle populations. Vet Microbiol 64:197-222

48. Lundborg GK, Svensson EC, Oltenacu PA (2005) Herd-level risk factors for infectious diseases in Swedish dairy calves aged 0-90 days. Prev Vet Med 68:123-143

49. Mars MH, Van Maanen C (2005) Diagnostic assays applied in BVDV control in the Netherlands. Prev Vet Med 72:43-48

50. Moen A, Sol J, Sampimon O (2005) Indication of transmission of BVDV in the absence of persistently infected (PI) animals. Prev Vet Med 72:93-98

51. Moerman A, Straver PJ, Dejong MCM, Quak J, Baanvinger T, Vanoirschot JT (1993) A long-term epidemiologic-study of bovine viral diarrhea infections in a large herd of dairy-cattle. Vet Rec 132:622-626 
52. Negron ME, Pogranichniy RM, Van Alstine W, Hilton WM, Levy M, Raizman EA (2012) Evaluation of horizontal transmission of bovine viral diarrhea virus type 1a from experimentally infected white-tailed deer fawns (Odocoileus virginianus) to colostrum-deprived calves. Am J Vet Res 73:257-262

53. Niskanen R (1993) Relationship between the levels of antibodies to bovine viral diarrhea virus in bulk tank milk and the prevalence of cows exposed to the virus. Vet Rec 133:341-344

54. Niskanen R, Lindberg A (2003) Transmission of bovine viral diarrhoea virus by unhygienic vaccination procedures, ambient air, and from contaminated pens. Vet J 165:125-130

55. Pasman EJ, Dijkhuizen AA, Wentink GH (1994) A state-transition model to simulate the economics of bovine virus diarrhoea control. Prev Vet Med 20:269-277

56. Presi P, Heim D (2010) BVD eradication in Switzerland-a new approach. Vet Microbiol 142:137-142

57. Presi P, Struchen R, Knight-Jones T, Scholl S, Heim D (2011) Bovine viral diarrhea (BVD) eradication in Switzerland-Experiences of the first two years. Prev Vet Med 99:112-121

58. Pritchard G (2001) Milk antibody testing in cattle. In Pract 23:542-549

59. Rat-Aspert O, Fourichon C (2010) Modelling collective effectiveness of voluntary vaccination with and without incentives. Prev Vet Med 93:265-275

60. Raue R, Harmeyer SS, Nanjiani IA (2011) Antibody responses to inactivated vaccines and natural infection in cattle using bovine viral diarrhoea virus ELISA kits: assessment of potential to differentiate infected and vaccinated animals. Vet J 187:330-334

61. Reichel MP, Hill FI, Voges H (2008) Does control of bovine viral diarrhoea infection make economic sense? N Z Vet J 56:60-66

62. Rikula U, Nuotio L, Aaltonen T, Ruoho O (2005) Bovine viral diarrhoea virus control in Finland 1998-2004. Prev Vet Med 72:139-142

63. Rossmanith W, Deinhofer M, Janacek R, Trampler R, Wilhelm E (2010) Voluntary and compulsory eradication of bovine viral diarrhoea virus in lower Austria. Vet Microbiol 142:143-149

64. Rossmanith W, Janacek R, Wilhelm E (2005) Control of BVDVinfection on common grassland-the key for successful BVDVeradication in lower Austria. Prev Vet Med 72:133-137

65. Saliki JT, Dubovi EJ (2004) Laboratory diagnosis of bovine viral diarrhea virus infections. Vet Clin N Am Food Anim Pract 20:69-83

66. Sandvik T (2004) Progress of control and prevention programs for bovine viral diarrhea virus in Europe. Vet Clin N Am Food Anim Pract 20:151-169

67. Sarrazin S, Veldhuis A, Méroc E, Vangeel I, Laureyns J, Dewulf J, Caij AB, Piepers S, Hooyberghs J, Ribbens S, Van Der Stede Y (2013) Serological and virological BVDV prevalence and risk factor analysis for herds to be BVDV seropositive in Belgian cattle herds. Prev Vet Med 108:28-37

68. Shannon AD, Mackintosh SG, Kirkland PD (1993) Identification of pestivirus carrier calves by an antigen-capture ELISA. Aust Vet J 70:74-76

69. Shannon AD, Richards SG, Kirkland PD, Moyle A (1991) An antigen-capture ELISA detects Pestivirus antigens in blood and tissues of immunotolerant carrier cattle. J Virol Methods 34:1-12

70. Siegwart N, Hilbe M, Hassig M, Braun U (2006) Increased risk of BVDV infection of calves from pregnant dams on communal Alpine pastures in Switzerland. Vet J 172:386-388

71. Solis-Calderon JJ, Segura-Correa VM, Segura-Correa JC (2005) Bovine viral diarrhoea virus in beef cattle herds of Yucatan, Mexico: seroprevalence and risk factors. Prev Vet Med 72:253-262

72. Synge BA, Clark AM, Moar JAE, Nicolson JT, Nettleton PF, Herring JA (1999) The control of bovine virus diarrhoea virus in Shetland. Vet Microbiol 64:223-229

73. Taylor LF, Janzen ED, Ellis JA, vandenHurk JV, Ward P (1997) Performance, survival, necropsy, and virological findings from calves persistently infected with the bovine viral diarrhea virus originating from a single Saskatchewan beef herd. Can Vet $\mathbf{J}$ 38:29-37

74. Taylor LF, Rodwell BJ (2001) Outbreak of foetal infection with bovine pestivirus in a central Queensland beef herd. Aust Vet J 79:682-685

75. Trautwein G, Hewicker M, Liess B, Orban S, Grunert E (1986) Studies on the transplacental transmissibility of a bovine virus diarrhoea (BVD) vaccine virus in cattle III. Occurrence of central nervous system malformations in calves born from vaccinated cows. J Vet Med Ser B 33:260-268

76. Truyers IGR, Mellor DJ, Norquay R, Gunn GJ, Ellis KA (2010) Eradication programme for bovine viral diarrhoea virus in Orkney 2001 to 2008 . Vet Rec 167:566-570

77. Valle PS, Skjerve E, Martin SW, Larssen RB, Osteras O, Nyberg $\mathrm{O}$ (2005) Ten years of bovine virus diarrhoea virus (BVDV) control in Norway: a cost-benefit analysis. Prev Vet Med 72:189-207

78. Van Campen H (2010) Epidemiology and control of BVD in the US. Vet Microbiol 142:94-98

79. Vanderheijden N, De Moerlooze L, Vandenbergh D, Chappuis G, Renard A, Lecomte C (1993) Expression of the bovine viral diarrhoea virus Osloss p80 protein: its use as ELISA antigen for cattle serum antibody detection. J Gen Virol 74:1427-1431

80. Zimmer GM, Van Maanen C, De Goey I, Brinkhof J, Wentink GH (2004) The effect of maternal antibodies on the detection of bovine virus diarrhoea virus in peripheral blood samples. Vet Microbiol 100:145-149 